\title{
Utilisation of pulp and paper industry wastes as raw materials in cement clinker production
}

\section{Fernando Castro and Cândida Vilarinho*}

Department of Mechanical Engineering,

University of Minho,

4800-058 Guimarães, Portugal

E-mail: fcastro@dem.uminho.pt

E-mail: candida@dem.uminho.pt

*Corresponding author

\section{Delfim Trancoso and Paula Ferreira}

Portucel Viana SA,

Apartado 550, 4901-852 Viana do Castelo, Portugal

E-mail: delfim.trancoso@gescartao.pt

E-mail: paula.ferreira@gescartão.pt

\section{Fernando Nunes and Augusto Miragaia}

\section{CMP SA,}

Fábrica Maceira Liz, 2405-019 Maceira - Leiria, Portugal

E-mail: antonio.nunes@secil.pt

E-mail: augusto.miragaia@secil.pt

\begin{abstract}
The present work assesses the incorporation of grits and dregs, both wastes from cellulose and paper making industry, in cement clinker production. Industrial trials were developed with conventional raw clinker, used as a reference material and with the addition of grits and dregs, $0.25 \%$ and $0.13 \%$, respectively. All raw meals were fired at $1400-1500^{\circ} \mathrm{C}$. Chemical composition of the final mixtures, gaseous emissions quality during clinker production and leaching behaviour of the final products were evaluated. The results show that such incorporation could be an effective process for waste management from both the environmental and economic points of view.
\end{abstract}

Keywords: dregs; grits; incorporation; waste management; raw materials; pulp and paper industry; clinker production.

Reference to this paper should be made as follows: Castro, F., Vilarinho, C., Trancoso, D., Ferreira, P., Nunes, F. and Miragaia, A. (2009) 'Utilisation of pulp and paper industry wastes as raw materials in cement clinker production', Int. J. Materials Engineering Innovation, Vol. 1, No. 1, pp.74-90.

Biographical notes: Fernando Castro is a full time Professor at the Mechanical Engineering Department of the University of Minho. He holds a degree in Metallurgical Engineering at the University of Porto (1982) and a $\mathrm{PhD}$ in Mechanical Engineering at the University of Minho (1988). His scientific and technical interests are in the area of waste management technologies, especially in the field of incorporation of residues in civil construction materials and 
recovery of metals from industrial wastes. His research activities cover also the development of ecomaterials, like lead-free brasses and electronic solders. Presently, he is the President of the Administration Board of Centre for Wastes Valorisation (CVR), which is a private non-profit research organisation, based in Guimarães, Portugal and working in the area of waste management.

Cândida Vilarinho is a Professor at the Mechanical Engineering Department of the University of Minho. She holds a degree in Metallurgical Engineering at the University of Porto (1989) and a PhD in Mechanical Engineering at the University of Minho (2000). Her scientific and technical interests are in the area of waste characterisation and management technologies. Development and characterisation of eco-materials, is another research area of interest.

Delfim Trancoso holds a degree in Chemical Engineering at the University of Porto (1982). He is the Department Head, who is responsible for Quality, Environment, Safety and Technical Statistics.

Paula Ferreira holds a degree in Chemical Engineering at the University of Coimbra (2002). She is a Senior Technician at the Environmental Laboratory.

António Fernando Neto Nunes holds a degree in Mechanical Engineering at the University of Coimbra. He is the Department Head, who is responsible for Environment, at Secil - Maceira Liz.

Augusto Manuel Pereira Miragaia holds a degree in Chemical Engineering at the Technical Institute of Coimbra. He is a Production Manager at Secil Maceira Liz.

\section{Introduction}

Four main processes are involved in pulp and paper industry, namely the chemical pulping (kraft process), mechanical and chemical-mechanical pulping, recycled fibre processing and paper-making related processes (Demir et al., 2005).

The raw materials are received as logs directly from the forest or as by-product chips from some other wood processing industries like sawmills and recovered fibres.

The chemical route is the most widely used and in the sulphate pulping process the active chemicals are sodium hydroxide $(\mathrm{NaOH})$ and sodium sulphide $\left(\mathrm{Na}_{2} \mathrm{~S}\right)$, which is known as the kraft process. In this, the fibres are liberated in the cooking plant by dissolving the lignin and part of the hemicellulose in the cooking chemical solution (white liquor), which contains sodium hydroxide and sodium sulphide as active chemicals. Because the pulp coming from the digester contains both fibres and spent cooking liquor (black liquor), the first step of preparation is washing. Subsequently, the pulp is prepared for the paper machine by a sequence of processes like dilution, refining and the addition of chemicals that aid the process and affect the final quality of the paper sheet.

Another production alternative consists in mixing the recovered paper with hot water or white water into a pulp. By mechanical and hydraulic agitation, this mixture is disintegrated into fibres. Contaminants and clusters are removed continuously during this operation. Once filtered, the pulp is pumped into hydrocyclones in order to remove 
smaller heavy weight particles and subsequently thickened to the consistency required by the paper machine.

Paper is made by introducing a dilute suspension of fibres on a fine mesh through which the water drains, leaving the web of fibres settling on the mesh. The paper web passes into a press section supported on felts between rollers, through the drying section and finally through a calendar.

In the kraft route vast amounts of inorganic solid wastes, including bottom and fly ashes, dregs and grits as well as organic wastes such as primary and biological sludge and brown stock screening rejects are generated (Gemelli et al., 2001; Jordan et al., 2002; Demir et al., 2005; Nurmesniemi et al., 2005). Dregs and grits are two wastes originated during the liquor causticising process, which has the main purpose to convert inactive sodium carbonate $\left(\mathrm{Na}_{2} \mathrm{CO}_{3}\right)$ into sodium hydroxide $(\mathrm{NaOH})$ at a high efficiency rate (Martins et al., 2007; Nurmesniemi et al., 2007).

The default method for handling these wastes is by dumping them in landfills. Although this method is the most widely used, it should be the last option according to the European Council Directive 75/442/EEC (EC, 1975).

This method presents a negative environmental impact, as consequence of groundwater pollution from leaching of toxic components, emission of odour and soil contamination (Saikia et al., 2007). In addition, it should be taken into account the economical disadvantages of this method due to the increasing of disposal costs as consequence of regulations designed to protect the environment and the decreasing of available landfilling areas (Jordan et al., 2002; Cabral et al., 1998; Muse and Mitchell, 1995; Nurmesniemi et al., 2007). Finally, waste can represent a loss of both materials and energy.

Alternative approaches for the management of grits and dregs include agricultural use. Various studies on the effect of these wastes in soils that are poor in organic matter and nutrients show that grits have an inhibitory behaviour for plant growth and soil microbial activity, while dregs as well as wood ashes enhance seed germination and seedling growth of Monterey pine, a common source of timber for pulping (Jordan et al., 2002). In brief, they can be suitable for soil fertilisation purposes and act as an amendment by increasing pH and water content (Jordan et al., 2002; Muse and Mitchell, 1995). As consequence of the high calcium carbonate equivalents, the addition of dregs and grits raises significantly the soil $\mathrm{pH}$, promoting neutralisation of soil acidity, which represents a valid and cost effective alternative to the use of commercial agricultural limestone (Nurmesniemi et al., 2005; Cabral et al., 2008).

Nurmesniemi et al. (2007) evaluate various alternative methods for waste management in the pulp industry. The authors describe a case study in which energy recovery, water treatment in closed loops, soil amelioration, material incorporation (hardener in mines cavities and hydraulic barrier) and landfilling are closely integrated.

Despite this application, new strategies for the management of wastes from cellulose industry, with a minimum impact for the environment, should be attempted. This is particularly relevant because their application in soil fertilisation is of seldom use in Portugal and direct landfill is common.

Several studies have shown that the incorporation of wastes and by-products in construction materials could be an economical and environmentally sound way to reuse wastes. Because they are coming from distinct industrial processes, exhibiting different characteristics and compositions, they may be used as partial substitutes of raw materials and/or as an alternative of primary fuel (Magalhães et al., 2004a; Rossetti and Medici, 
1995; ECOINERT, 1999, ECOCERAM2, 2005, Barros et al., 2004; Galbenis and Tsimas, 2006; Andrade et al., 2003) with direct benefits of resource and energy conservation (Tsakiridis et al., 2008).

Examples of wastes successfully tested as an alternative raw material for materials construction include municipal solid waste incineration fly ash, steel slag, phosphate-coating sludge and several compounds namely $\mathrm{ZnO}, \mathrm{PbO}$ and $\mathrm{CdO}$ amongst others (Barros et al., 2004; Saikia et al., 2007; Tsakiridis et al., 2008; Caponero and Tenório, 2000).

The waste incorporation in construction materials also enables the stabilisation of toxic substances and heavy metals, reducing its potential toxicity by lowering components mobility (Trezza and Scian, 2007; Andrade et al., 2003; Magalhães et al., 2004b).

Several incorporation techniques provide a reliable and sustainable alternative to the residues from the paper processing industry, either by a partial replacement of cement and/or sand by bottom ash, fibres, dregs and grits into mortar for construction applications (Gemelli et al., 2001) or by the incorporation of organic wastes from kraft pulp production, straw and reed residues, in brick-clay, acting as an organic pore-forming agent (Demir et al., 2005).

Therefore, the development of new methods to assure a correct management of dregs and grits is necessary. Incorporation of these wastes in clinker production may be an alternative to their current landfilling disposal. This industrial process involves a phase where calcium carbonate is decomposed into lime in a high temperature process (approximately $800^{\circ} \mathrm{C}$ ) to produce an intermediate product, called clinker, which is a base material for all Portland cement formulations. The main raw material in clinker fabrication is limestone, to which other substances are added, such as quartz sand (silicon oxide), aluminium and iron oxides. The raw mix is heated in a rotary kiln, where limestone is decomposed into calcium oxide, enhancing the formation of calcium silicates phases, relevant to obtain cement pozzolanic properties.

Papermaking wastes like dregs (LER code 0303 02) and grits (LER code 0303 09), normally rated as non-hazardous wastes according to Commission Decision 2000/532/CE of 3 May 2000 (EC, 2000), are characterised by high calcium carbonate contents, which may be interesting in view of potential use as raw materials for clinker production.

However, any solution must be compatible with the quality standards of the product and do not contribute to high emission levels. In the present research work, the incorporation of these papermaking residues in clinker production has been studied, at an industrial scale and evaluated in terms of the inherent environmental impact. Most of the work concerning the incorporation of residues into construction materials is based upon tests at laboratory or pilot scale (Trezza and Scian, 2007; Barros et al., 2004; Saikia et al., 2007; Tsakiridis et al., 2008; Caponero and Tenório, 2000). In the present work, a full scale industrial assessment of the impact of a paper mill waste into clinker makes the results of high relevance to the management of such wastes. 
Figure 1 Flow diagram of the production of wastes during paper manufacture

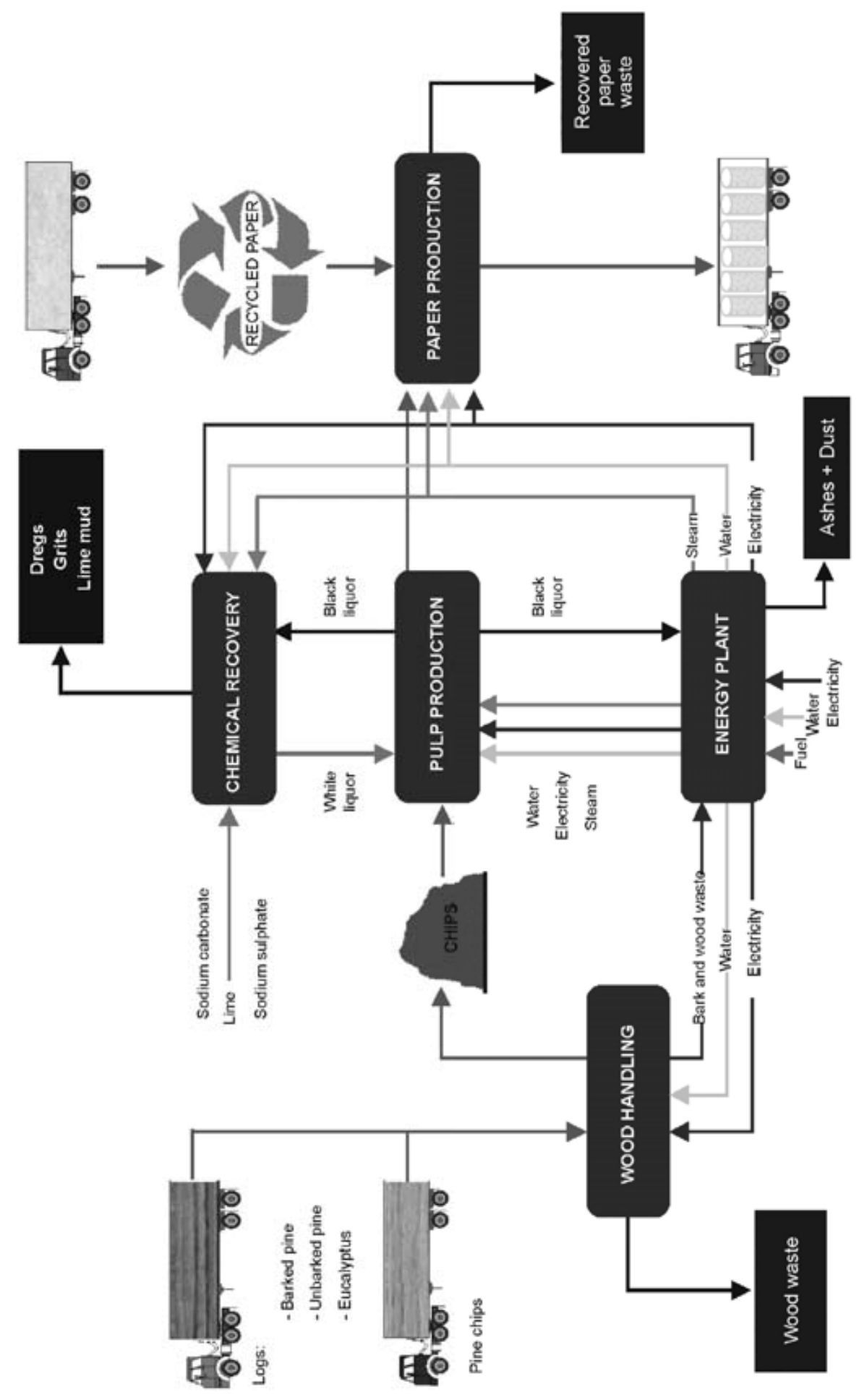




\section{Materials/experimental}

\subsection{Wastes characterisation}

Samples of dregs and grits, from the cellulose industry using kraft process, have been supplied by Gescartão, SA, a paper plant at Viana do Castelo, in Northern Portugal. The plant produces approximately 280,000 tonnes of paper per year, using pine and eucalyptus wood as raw materials.

For this particular plant, in a single year, a total of around 2,900 tonnes of dregs and 220 tonnes of grits are generated on a wet basis. These inorganic waste materials, presently landfilled, are originated during liquor causticising, according to the diagram presented in Figure 1. Dregs result from the filtration of green liquor in a rotating drum. They represent the wastes from the combustion of the black liquor in the recovery boiler and grits are produced during the reaction of quick lime (calcium oxide) with the water that accomplishes the green liquor. Their chemical composition is dependent on the manufacturing processes and raw materials (Nurmesniemi et al., 2007).

Figure 2 Solid wastes from paper manufacture (a) dregs and (b) grits

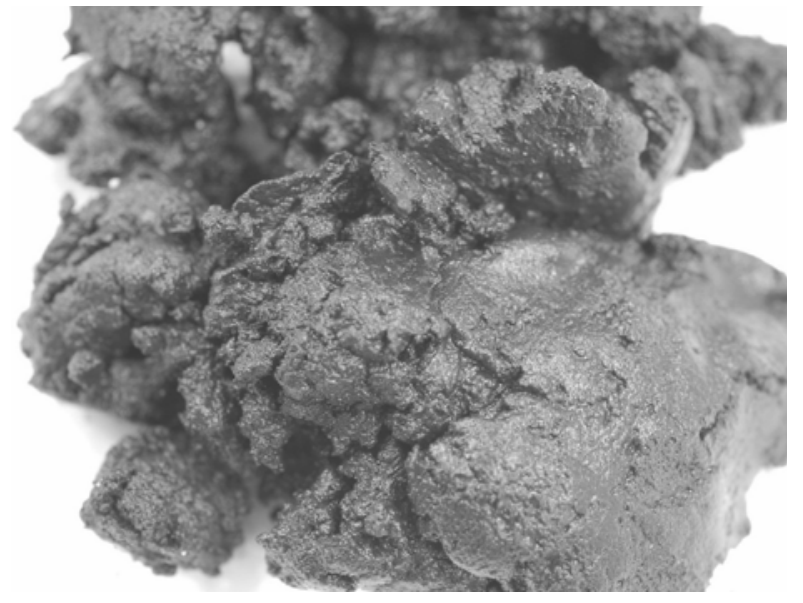

(a)

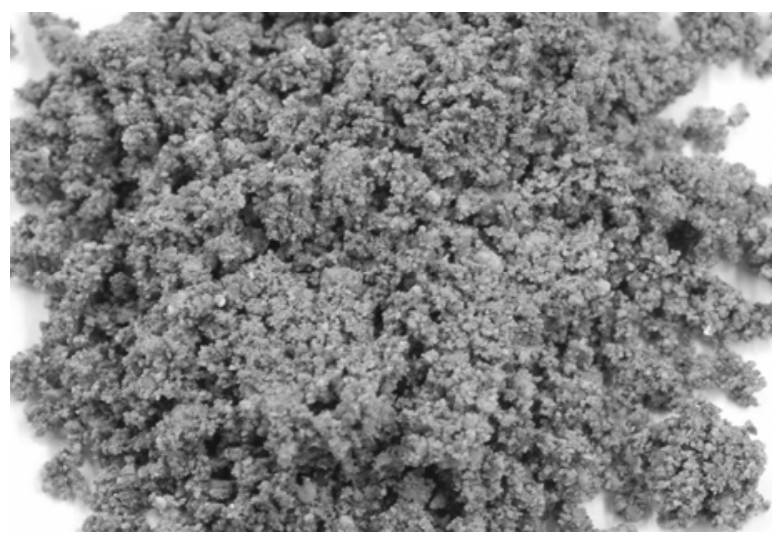

(b) 
Samples of dregs and grits, as shown in Figure 2, have been characterised for its chemical, mineralogical and physical properties. Their chemical composition was evaluated by X-ray fluorescence spectrometry, using a Philips X UniqueII spectrometer. For that purpose, samples were dried, mixed with wax and pressed into a pellet. The results, shown in Table 1, illustrate that the main component in grits waste is calcium carbonate. Hydrated sodium carbonate and phosphorous oxide are also present in a lower content. However, the analysis of dregs reveals a high content of organic materials (up to $30 \%$ ) as shown in Table 1 from a mass balance. Other compounds, mainly calcium carbonate, hydrated sodium carbonate, sulphate, magnesium, iron and potassium oxides are also detected in this waste. Metallic elements, such as $\mathrm{Mn}$ and $\mathrm{Zn}$, are also observed in dregs samples. This observation is expected because during the causticising operation the non-process metals are purged from the process and precipitated in the green liquor (Nurmesniemi et al., 2005). Based upon this analysis, both dregs and grits show potential to be directly incorporated in clinker manufacture, since they have some of the major components present in conventional raw materials used in the clinkering process, namely $\mathrm{CaCO}_{3}, \mathrm{MgO}, \mathrm{Fe}_{2} \mathrm{O}_{3}$ and $\mathrm{K}_{2} \mathrm{O}$.

Table 1 Chemical composition of the wastes

\begin{tabular}{lcc}
\hline & Dregs & Grits \\
\hline $\mathrm{CaCO}_{3}$ & 22.1 & 92.1 \\
$\mathrm{SiO}_{2}$ & 0.15 & 0.06 \\
$\mathrm{SO}_{4}$ & 12.8 & 0.55 \\
$\mathrm{~K}_{2} \mathrm{O}$ & 2.5 & 0.06 \\
$\mathrm{Al}_{2} \mathrm{O}_{3}$ & 1.1 & 0.08 \\
$\mathrm{Fe}_{2} \mathrm{O}_{3}$ & 3.9 & 0.29 \\
$\mathrm{MgO}$ & 6.4 & 0.36 \\
$\mathrm{TiO}_{2}$ & 0.09 & 0.05 \\
$\mathrm{Na}_{2} \mathrm{CO}_{3} \mathrm{H}_{2} \mathrm{O}$ & 16.4 & 1.5 \\
$\mathrm{P}_{2} \mathrm{O}_{5}$ & 0.23 & 2.3 \\
$\mathrm{Cl}$ & 0.60 & $<0.02$ \\
$\mathrm{~V}$ & $<0.02$ & $<0.02$ \\
$\mathrm{Cr}$ & 0.03 & $<0.02$ \\
$\mathrm{Mn}$ & 2.6 & $<0.02$ \\
$\mathrm{Ni}$ & 0.11 & $<0.02$ \\
$\mathrm{Cu}$ & 0.11 & $<0.02$ \\
$\mathrm{Zn}$ & 0.47 & 0.02 \\
$\mathrm{Rb}$ & $<0.02$ & $<0.02$ \\
$\mathrm{Sr}$ & 0.03 & 0.05 \\
$\mathrm{Zr}$ & 0.06 & $<0.02$ \\
$\mathrm{Ba}$ & $<0.02$ & 0.04 \\
$\mathrm{~Pb}$ & $<0.02$ & 0.02 \\
$\mathrm{Other*}$ & $<a l a n c e$ \\
\hline $\mathrm{Na}$ & &
\end{tabular}

Note: *mainly organic materials 
Figure 3 XRD of (a) dregs and (b) grits used

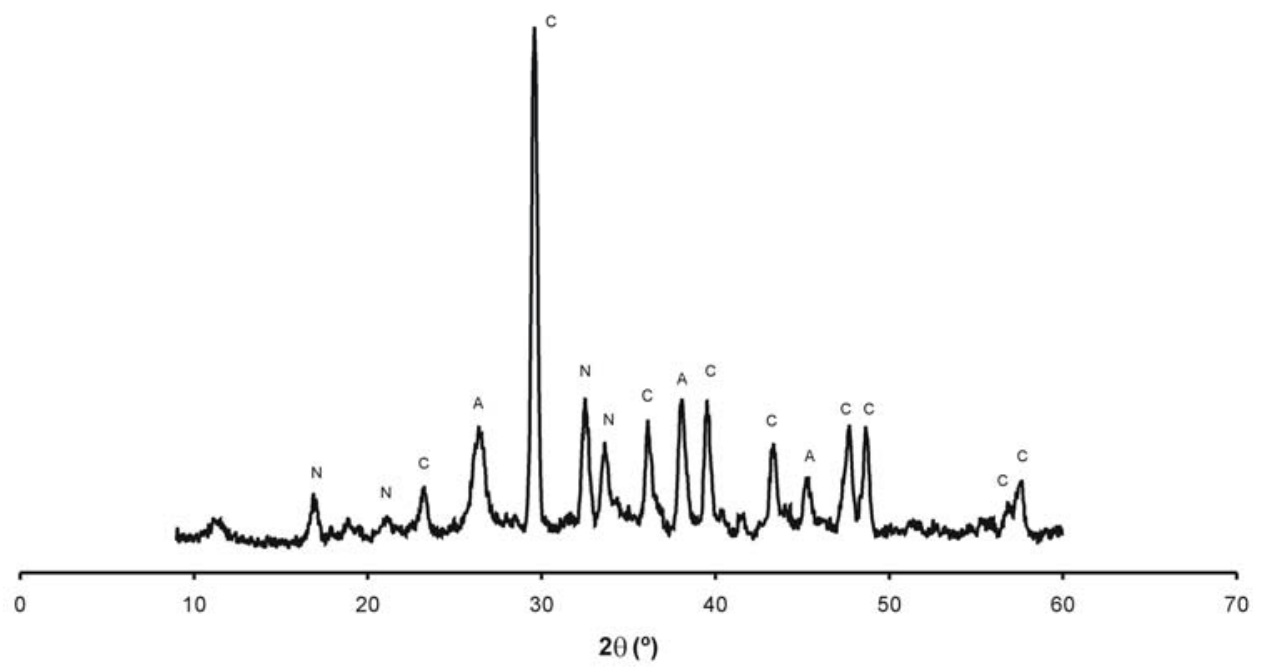

(a)

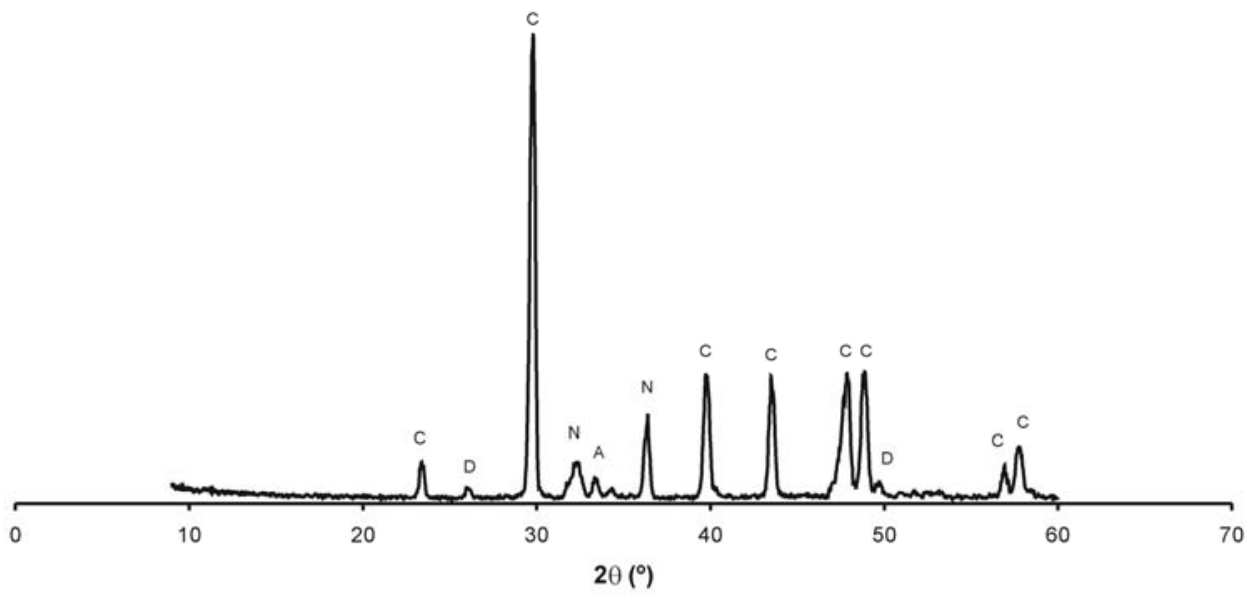

(b)

Notes: $\mathrm{C}$ - calcite $\left(\mathrm{CaCO}_{3}\right) ; \mathrm{A}$ - aragonite $\left(\mathrm{CaCO}_{3}\right) ; \mathrm{N}$ - sodium carbonate $\left(\mathrm{Na}_{2} \mathrm{CO}_{3} \cdot \mathrm{H}_{2} \mathrm{O}\right) ; \mathrm{D}$ - dahllite

X-ray diffraction (XRD) measurements were carried out in dried samples in order to identify the mineralogical phases present in the solid residues generated in kraft process. The powder XRD patterns were collected in step-scan regime (step $0.04^{\circ}$ and time $1 \mathrm{~s}$ ) on a Bruker D8 Discover diffractometer operating with $\mathrm{CuK}_{\alpha 1,2}$ radiation in the range $2 \theta 9-60^{\circ}$. The phases were identified by using the International Centre for Diffraction Data (ICDD) database. The corresponding diffraction peaks of dregs and grits are shown in Figure 3. In both wastes, it is possible to observe the co-existence of the two 
modifications of the $\mathrm{CaCO}_{3}$ : calcite and aragonite and also the presence of sodium carbonate $\left(\mathrm{Na}_{2} \mathrm{CO}_{3} \mathrm{H}_{2} \mathrm{O}\right)$.

Considering some of the peak shifts, it is possible to suggest that there is a partial isomorphous substitution of $\mathrm{Ca}$ by $\mathrm{Mn}$ and/or $\mathrm{Mg}$. Peaks of lower intensity, corresponding to material with dahllite structure (carbonate rich apatite), are detected in grits sample, which is in agreement with its chemical analysis.

Figure 4 Particle size distribution (cumulative curve) of dregs and grits

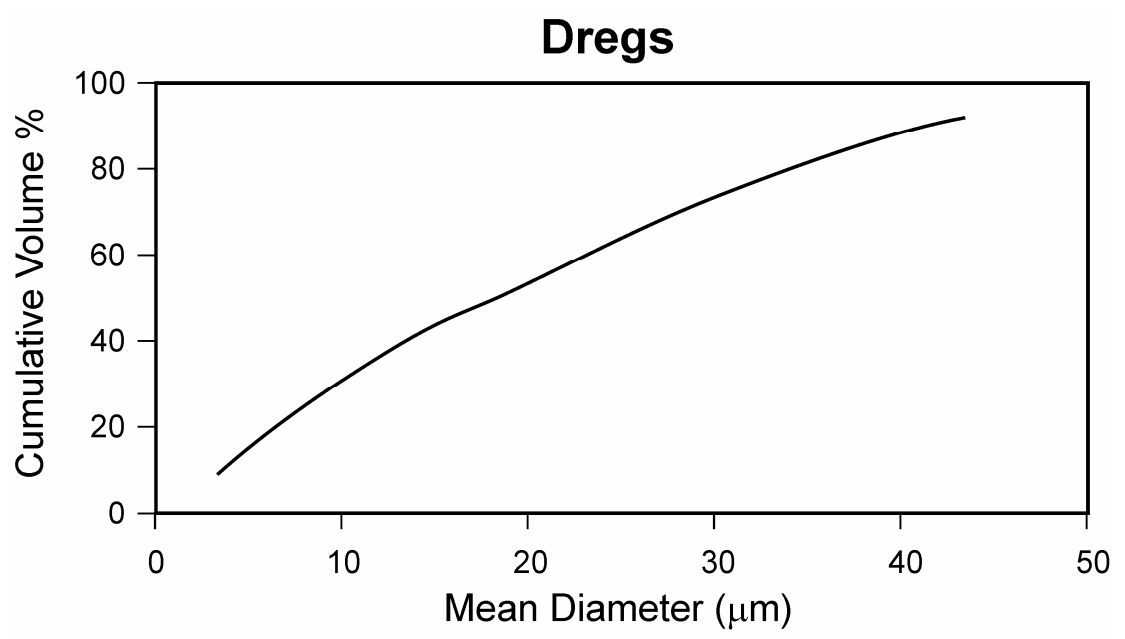

\section{Grits}

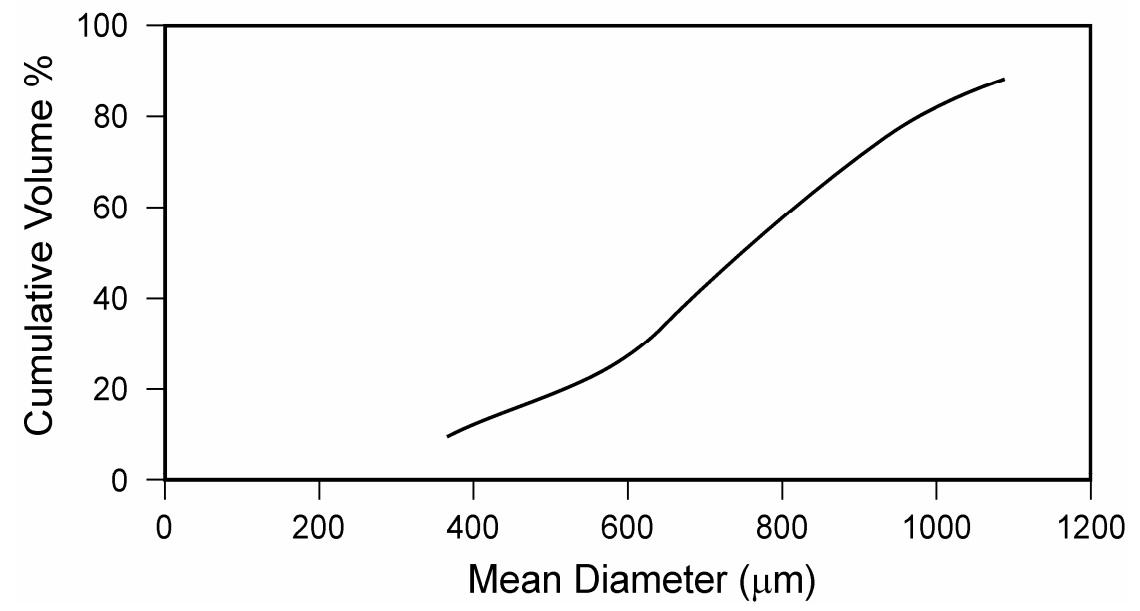

Moisture content has been determined and a value of $78 \%$ for dregs and $16 \%$ for grits was found. The different physical-chemical conditions during their formation are responsible for the distinct moisture levels. A combination of a laser scattering technique (Beckman Coulter LS230) and calibrated sieves was used to measure the waste particle size. The results are shown in Figure 4 for both dregs and grits. The particle size distribution suggest that such residues can be directly incorporated with conventional raw materials for clinker production, without any further grinding or any other kind of 
pre-treatment. If the particle size is of great benefit, the high moisture level is open to debate, as consequence of the energy bill associated with it. Pre-drying the residues would reduce the amount of energy required in the clinker firing, but by the same amount that would be necessary for the drying operation, bringing no net gain. There would be some benefit in the transportation because the total mass would be greatly reduced. However, this would require additional dryer, which is always an expensive equipment, whose costs will be shouldered by the producer of the waste. In such circumstances, this route of waste treatment would be rendered unattractive.

\subsection{Industrial trials}

Industrial experimentation has been carried out in the clinker plant of Maceira, from Secil, SA, which is located in the centre of Portugal. This plant produces approximately $1.4 \times 10^{6}$ tonnes per year of cement. In clinker production, raw materials, such as limestone and shale, are quarried and after the preliminary homogenisation, the materials are crushed and conveyed into the clinker kiln. The clinker is fired at $1400^{\circ} \mathrm{C}-1500^{\circ} \mathrm{C}$ and the final product, Figure 5, is then fine grounded and mixed with gypsum and mineral components to produce cement, according to the flux diagram depicted in Figure 6.

Figure 5 Clinker material

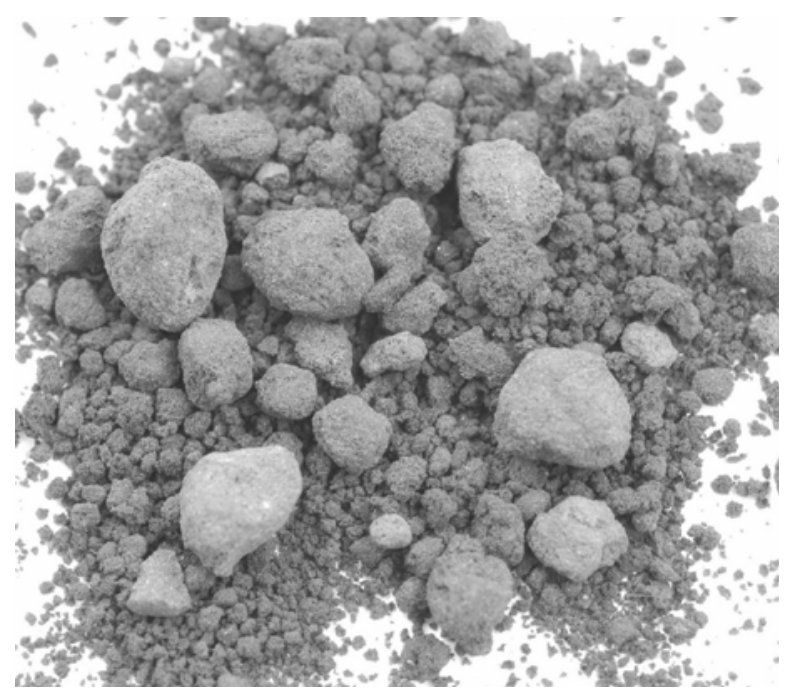

Three industrial trials have been developed, one using the raw mixtures prepared with the standard materials for clinker production, used as reference material and two prepared by mixing the clinker raw material with $0.13 \%$ of dregs and $0.25 \%$ of grits, based upon the total raw mix employed in the plant. Although such percentages are very small, they can account for all the waste production from a single paper pulp plant. Therefore, increasing the incorporation levels is of no practical relevance. Dregs (20 ton) and grits (40 ton) have been added and mixed to the standard clinker raw mixtures (heap with a total mass of 16,000 ton) in order to achieve the desired level of incorporation. The chemical composition of the conventional raw materials used in clinker manufacture and of the raw mixes prepared for the experimental trials were determined by $\gamma$-Rays and X-ray 
fluorescence techniques. Raw meals were fired at $1400-1500^{\circ} \mathrm{C}$, into the clinker kiln. The presence of wastes did not introduce any difficulties during the mixing and burning processing. Each trial was run for a period of approximately 24 hours and during this period the gaseous emissions were continuously monitored, for the most relevant contaminants such as particles, $\mathrm{SO}_{2}, \mathrm{CO}, \mathrm{TOC}, \mathrm{NO}_{\mathrm{x}}$, amongst others.

Figure 6 Flow chart of cement production

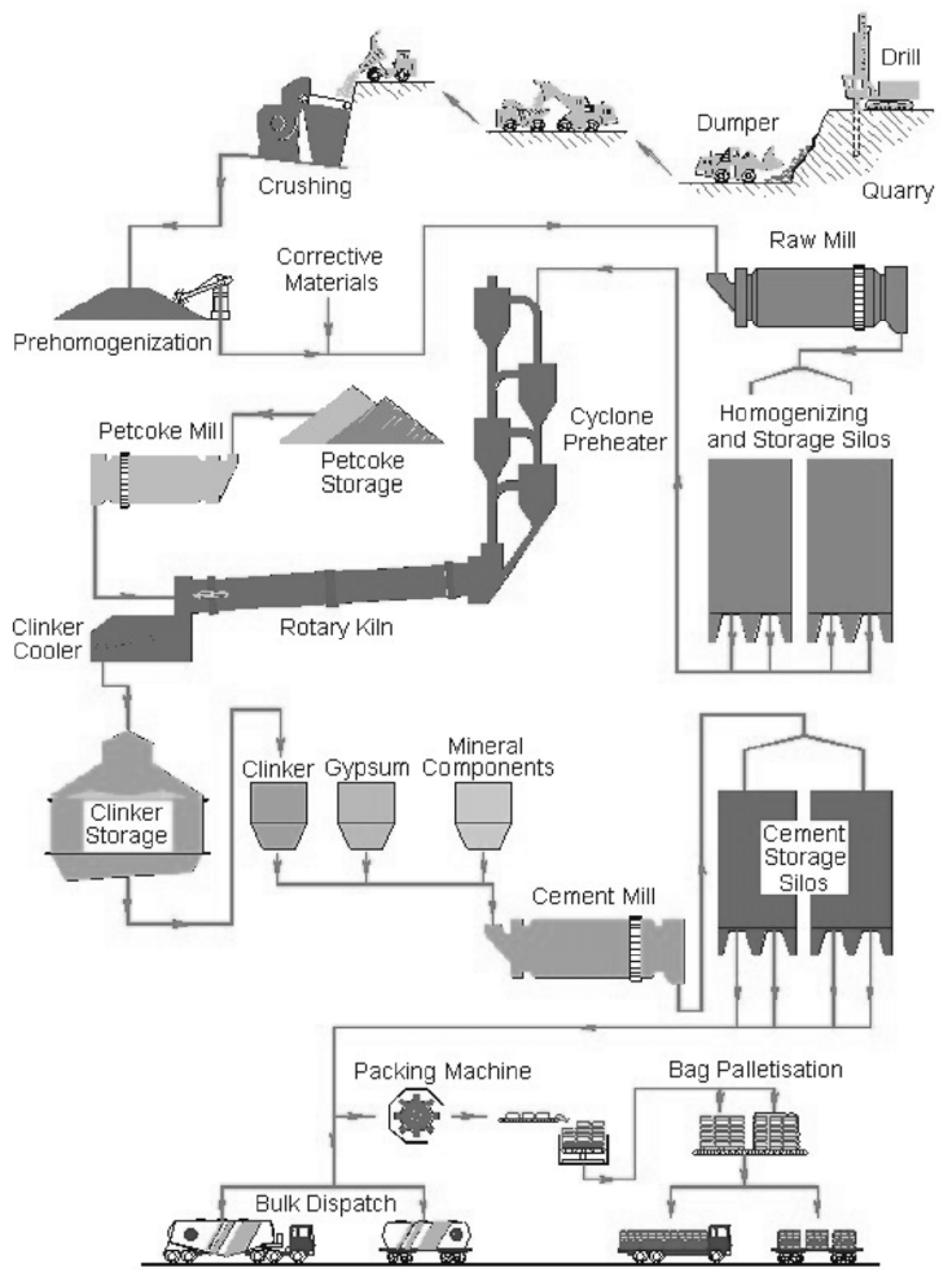


Also, samples of the produced clinker have been collected during the industrial trials, in order to determine its leaching behaviour for environmental evaluation. For this purpose a leaching procedure, according to DIN 38414-S4 (DIN, 1984) has been followed. In this, a sample made of $100 \mathrm{~g}$ of material (clinker or clinker + wastes) per $\mathrm{dm}^{3}$ of water, was turned at 0.5 turns per minute, for a period of 24 hours at room temperature. Once filtered, the leaching solution was analysed for the most relevant parameters.

\section{Results and discussions}

When evaluating the influence of wastes incorporation in the clinker production it was found that no additional pre-treatment and modifications to the production process were required. Their physical characteristics (grain size and moisture content) enable their correct incorporation on a wet basis and direct mixing with the raw materials.

Based upon the levels of waste incorporation, the total amount of water introduced is approximately 2,600 tonnes per year and the energy load due to that moisture is $5.8 \times 10^{6} \mathrm{MJ} / \mathrm{year}$. This figure represents a very small fraction in the overall energy consumption of the clinker plant.

Table 2 Typical chemical composition of the raw mixtures for clinker production and chemical compositions of the raw mixtures used in the experimental trials

\begin{tabular}{lcccc}
\hline Compounds & Average & Standard deviation & $0.1 \%$ dregs & $0.25 \%$ grits \\
\hline $\mathrm{CaCO}_{3}$ & 76.6 & 0.29 & 76.4 & 76.6 \\
$\mathrm{CaO}$ & 43.0 & 0.37 & 42.8 & 42.9 \\
$\mathrm{SiO}_{2}$ & 13.6 & 0.31 & 13.3 & 13.4 \\
$\mathrm{Al}_{2} \mathrm{O}_{3}$ & 3.4 & 0.12 & 3.3 & 3.4 \\
$\mathrm{Fe}_{2} \mathrm{O}_{3}$ & 1.5 & 0.20 & 1.3 & 1.5 \\
$\mathrm{~K}_{2} \mathrm{O}$ & 0.65 & 0.15 & 0.39 & 0.60 \\
$\mathrm{MgO}$ & 1.4 & 0.46 & 1.7 & 1.3 \\
$\mathrm{SO}_{3}$ & 1.1 & 0.28 & 1.2 & 0.95 \\
\hline
\end{tabular}

The results have shown that adding dregs and grits, for the content levels incorporated in the tests, did not promote significant changes in the conventional chemical composition of the raw meals for clinker production (Table 2), which consists mostly of $\mathrm{CaCO}_{3}, \mathrm{CaO}$, $\mathrm{SiO}_{2}$ and in smaller amounts of $\mathrm{Al}_{2} \mathrm{O}_{3}, \mathrm{Fe}_{2} \mathrm{O}_{3}, \mathrm{~K}_{2} \mathrm{O}, \mathrm{MgO}$ and $\mathrm{SO}_{3}$. Considering the average and standard deviation of raw meals composition in the clinker process historical data, the variations detected for the raw mix with wastes incorporation are within the process variability.

The environmental evaluation of incorporating wastes into the production process was based in two different parameters:

- quality of gaseous emissions

- leaching behaviour of the clinker material.

The first item is obvious, as cement plants have to comply with strict environmental limits for pollutants of gaseous effluents. Hence, the evaluation has been carried out 
according to the appropriate legislation, as well as to overall modification of gaseous characteristics.

Table 3 Emissions produced during the manufacture of clinker, in normal operation and in the industrial tests of residues incorporation

\begin{tabular}{|c|c|c|c|c|c|c|c|}
\hline \multirow{2}{*}{ Parameter } & \multicolumn{2}{|c|}{ Normal operation } & \multicolumn{2}{|c|}{$0.13 \%$ dregs } & \multicolumn{2}{|c|}{$0.25 \%$ grits } & \multirow{2}{*}{$\begin{array}{c}\begin{array}{l}\text { Legal } \\
\text { limits }\end{array} \\
-\end{array}$} \\
\hline & Average & $\begin{array}{l}\text { Standard } \\
\text { deviation }\end{array}$ & Average & $\begin{array}{l}\text { Standard } \\
\text { deviation }\end{array}$ & Average & $\begin{array}{l}\text { Standard } \\
\text { deviation }\end{array}$ & \\
\hline $\begin{array}{l}\text { Flow gases } \\
\left(\mathrm{Nm}^{3} / \mathrm{h}\right)\end{array}$ & 195,015 & 12,535 & 189,461 & 19,472 & 195,579 & 21,032 & - \\
\hline $\begin{array}{l}\text { Temperature } \\
\left({ }^{\circ} \mathrm{C}\right)\end{array}$ & 121 & 5.2 & 120 & 5.8 & 119 & 5.6 & - \\
\hline $\begin{array}{l}\text { Particles } \\
\left(\mathrm{mg} / \mathrm{Nm}^{3}\right)\end{array}$ & 12.8 & 1.9 & 17.3 & 3.4 & 8.3 & 1.6 & 50 \\
\hline $\begin{array}{l}\mathrm{HCl} \\
\left(\mathrm{mg} / \mathrm{Nm}^{3}\right)\end{array}$ & 2.0 & 1.1 & 2.2 & 3.3 & 2.2 & 2.9 & 250 \\
\hline $\begin{array}{l}\mathrm{HF} \\
\left(\mathrm{mg} / \mathrm{Nm}^{3}\right)\end{array}$ & 0.10 & 0.10 & 0.10 & 0.10 & 0.10 & 0.10 & 50 \\
\hline $\begin{array}{l}\mathrm{SO}_{2} \\
\left(\mathrm{mg} / \mathrm{Nm}^{3}\right)\end{array}$ & 198 & 80 & 493 & 178 & 147 & 59.7 & 400 \\
\hline $\begin{array}{l}\mathrm{NO}_{\mathrm{x}} \\
\left(\mathrm{mg} / \mathrm{Nm}^{3}\right)\end{array}$ & 490 & 124 & 373 & 136 & 617 & 160 & 1,300 \\
\hline $\begin{array}{l}\mathrm{CO} \\
\left(\mathrm{mg} / \mathrm{Nm}^{3}\right)\end{array}$ & 560 & 142 & 489 & 139 & 560 & 141 & 1,000 \\
\hline $\begin{array}{l}\mathrm{NH}_{3} \\
\left(\mathrm{mg} / \mathrm{Nm}^{3}\right)\end{array}$ & 15.9 & 11.3 & 16.2 & 11.3 & 8.7 & 5.2 & - \\
\hline $\begin{array}{l}\text { TOC } \\
\left(\mathrm{mg} / \mathrm{Nm}^{3}\right)\end{array}$ & 45.0 & 4.9 & 40.2 & 3.9 & 41.6 & 3.5 & 50 \\
\hline $\mathrm{CO}_{2}(\mathrm{vol} \%)$ & 15.8 & 0.45 & 15.9 & 0.4 & 15.5 & 0.5 & - \\
\hline $\mathrm{H}_{2} \mathrm{O}(\mathrm{vol} \%)$ & 12.4 & 0.65 & 12.0 & 1.0 & 12.6 & 1.0 & - \\
\hline $\mathrm{O}_{2}(\mathrm{vol} \%)$ & 10.3 & 0.55 & 10.4 & 0.7 & 10.1 & 0.6 & - \\
\hline
\end{tabular}

The second aspect to be evaluated, takes into account that the cement will be, at the end of its lifecycle, a waste material. As a matter of fact, after a certain time, the construction will be subject to demolition and cement will be a constituent of a construction and demolition waste. With this regard, the waste must remain as an inert material. Subsequent landfilling would be considered as the worse case scenario and to evaluate the possible impacts associated with its disposal, a leaching test, according to DIN 38414-S4 standards has been followed. The resulting leaching solutions have been analysed regarding several parameters, including $\mathrm{pH}$, conductivity, total organic carbon (TOC), fluoride, phenols, absorbable organic halogen (AOX), chloride, sulphate, nitrite, ammonium and distinct metals and the results compared with Portuguese environmental legislation regulated by the Decree 152/2002 (PT Decree, 2002). In Table 3 of its Annex III, the limits concerning its landfill for inert, non-hazardous and hazardous wastes receiving landfills are clearly defined. The results were also compared with those obtained when no residues were added to the clinker. 
The results regarding the quality of gaseous emissions are presented in Table 3. As an overall comment, one may say that the incorporation of wastes in the raw mix of clinker production shows no significant effect in the emissions quality when compared with the values obtained in normal conditions, except for sulphur dioxide in the trial with $0,13 \%$ of dregs, which presents a statistically significant increase. Even if the obtained value is not statistically higher than the legal limit (taking into account the standard deviation of the measures) this suggests that the content of dregs to be incorporated should be limited. This is, in fact, the sole concern about the gaseous emissions when these residues are incorporated.

Table 4 Results of leaching evaluation of clinker samples

\begin{tabular}{|c|c|c|c|}
\hline Parameters & Analytical methods & Standard & $0.13 \%$ dregs \\
\hline $\mathrm{pH}$ & Electrometry & 12.0 & 12.9 \\
\hline Conductivity (mS/cm) & Electrometry & 6.7 & 12.4 \\
\hline TOC (mg C/L) & TC-IC & 8 & 16 \\
\hline Fluoride (mg/L) & $\mathrm{SM} 4500 \mathrm{~F}^{-} \mathrm{D}$ & $<0.190$ & $<0.190$ \\
\hline Phenols (mg/L) & SM $5530 \mathrm{D}$ & $<0.0003$ & $<0.0003$ \\
\hline Arsenic (mg/L) & SM 3500 As B & $<0.002$ & $<0.002$ \\
\hline Mercury $(\mathrm{mg} / \mathrm{L})$ & SM $3500 \mathrm{Hg}$ & $<0.001$ & $<0.001$ \\
\hline $\mathrm{AOX}(\mathrm{mg} \mathrm{Cl} / \mathrm{L})$ & DIN 38409-H14 & 0.04 & 0.71 \\
\hline Nitrite $(\mathrm{mg} / \mathrm{L})$ & NP EN 26777 & $<0.04$ & $<0.04$ \\
\hline Ammonium (mg/L) & LAE; UV-Vis & $<0.13$ & $<0.13$ \\
\hline Cyanide (mg/L) & $\mathrm{SM} 4500 \mathrm{CN}^{-} \mathrm{K}$ & $<0.05$ & $<0.05$ \\
\hline Copper (mg/L) & IM; AAS & $<0.025$ & $<0.025$ \\
\hline Chromium VI (mg/L) & MI; UV-Vis & $<0.05$ & $<0.05$ \\
\hline Total chromium (mg/L) & IM; AAS & $<0.05$ & $<0.05$ \\
\hline Nickel (mg/L) & IM; AAS & $<0.04$ & $<0.04$ \\
\hline Lead $(\mathrm{mg} / \mathrm{L})$ & IM; AAS & $<0.06$ & $<0.06$ \\
\hline Zinc $(\mathrm{mg} / \mathrm{L})$ & IM; AAS & $<0.008$ & $<0.008$ \\
\hline Cadmium (mg/L) & IM; AAS & $<0.009$ & $<0.009$ \\
\hline Chloride $(\mathrm{mg} / \mathrm{L})$ & $\mathrm{SM} 4500 \mathrm{Cl}^{-} \mathrm{B}$ & $<5$ & 90 \\
\hline Sulphate $(\mathrm{mg} / \mathrm{L})$ & LAE; UV-Vis & 325 & 340 \\
\hline
\end{tabular}

Notes: $\mathrm{IM}=$ internal method; $\mathrm{TOC}=$ total organic carbon; $\mathrm{TC}=$ total carbon; $\mathrm{IC}=$ inorganic carbon; AAS $=$ atomic absorption spectrometer; $\mathrm{UV}$-Vis = ultraviolet-visible spectrophotometer; $\mathrm{SM}=$ standard methods; LAE=L'Analyse de L'Eau; AOX = adsorbable organic halogen. 
Table 4 Results of leaching evaluation of clinker samples (continued)

\begin{tabular}{|c|c|c|c|}
\hline \multirow{2}{*}{ Parameters } & \multirow{2}{*}{$0.25 \%$ grits } & \multicolumn{2}{|c|}{ Limits } \\
\hline & & Inert & Non hazardous \\
\hline $\mathrm{pH}$ & 12.1 & $5.5<x<12$ & $4<x<13$ \\
\hline Conductivity (mS/cm) & 6.4 & $6<y<50$ & - \\
\hline TOC (mg C/L) & 6 & 40 & 100 \\
\hline Fluoride (mg/L) & $<0.190$ & 5 & 25 \\
\hline Phenols (mg/L) & $<0.0003$ & 1 & 10 \\
\hline Arsenic (mg/L) & $<0.002$ & 0.1 & 0.5 \\
\hline Mercury (mg/L) & $<0.001$ & 0.02 & 0.05 \\
\hline $\mathrm{AOX}(\mathrm{mg} \mathrm{Cl} / \mathrm{L})$ & 0.11 & 0.3 & 1.5 \\
\hline Nitrite (mg/L) & $<0.04$ & 3 & 10 \\
\hline Ammonium (mg/L) & $<0.13$ & 5 & 200 \\
\hline Cyanide (mg/L) & $<0.05$ & 0.1 & 0.5 \\
\hline Copper (mg/L) & $<0.025$ & 2 & 5 \\
\hline Chromium VI (mg/L) & $<0.05$ & 0.1 & 0.1 \\
\hline Total chromium (mg/L) & $<0.05$ & 0.5 & 2 \\
\hline Nickel (mg/L) & $<0.04$ & 0.5 & 1 \\
\hline Lead (mg/L) & $<0.06$ & 0.5 & 1 \\
\hline Zinc (mg/L) & $<0.008$ & 2 & 5 \\
\hline Cadmium (mg/L) & $<0.009$ & 0.1 & 0.2 \\
\hline Chloride (mg/L) & 8 & 500 & 5,000 \\
\hline Sulphate $(\mathrm{mg} / \mathrm{L})$ & 315 & 500 & 1,500 \\
\hline
\end{tabular}

Notes: $\mathrm{IM}=$ internal method; $\mathrm{TOC}=$ total organic carbon; $\mathrm{TC}=$ total carbon;

$\mathrm{IC}=$ inorganic carbon; AAS $=$ atomic absorption spectrometer;

$\mathrm{UV}$-Vis = ultraviolet-visible spectrophotometer; $\mathrm{SM}=$ standard methods;

$\mathrm{LAE}=\mathrm{L}$ 'Analyse de L'Eau; AOX = adsorbable organic halogen.

The results obtained for the environmental evaluation of clinker with the addition of wastes, presented in Table 4, enables its classification as a non-hazardous material, for disposal purposes. Although the results of the chemical analysis of the leaching solutions, by the application of different analytical methods, show that TOC, AOX or chloride levels in clinker with incorporation of dregs are higher than those observed in clinker with grits, these values are far below the limits for the disposal of inert or non hazardous wastes. Sulphate concentration and low level of metal dissolution are similar for all leached materials, including the clinker used as reference, meeting the legal criteria for the disposal of inert wastes. Based on this, no limitations for the implementation of the process have been detected, in what concerns environmental aspects.

For all the cases, clinker, at the end of its lifecycle, when considered as waste material, should be accepted in landfills for non-hazardous residues. Because no significant effects have been detected, it may be concluded that the addition of the papermaking residues does not affect clinker characteristics, from the point of view of future waste material management. 
Standard probes were prepared to measure compression and bending strength. Tests were carried out for aging periods of 2, 7 and 28 days. The results (Table 5) show that the mechanical strength (for both bending and compression) increases with aging time.

Table 5 Typical values of mechanical properties of clinker (MPa)

\begin{tabular}{ccccccc}
\hline \multicolumn{3}{c}{ Bending strength } & & \multicolumn{3}{c}{ Compression strength } \\
\cline { 1 - 3 } \cline { 6 - 7 } \cline { 5 - 7 } 2 days & 7 days & 28 days & & 2 days & 7 days & 28 days \\
\hline 4.6 & 6.6 & 8.3 & & 22.1 & 34.1 & 46.7 \\
\hline
\end{tabular}

Although a full characterisation of the mechanical properties of the clinker mix with wastes has not been carried out, it is expected that they do not differ significantly from the standard material. In fact, the chemical composition of such raw mix is within the deviation observed with pure clinker and the level of waste incorporation is kept at such low levels that the final product is expected to comply with standards.

\section{Conclusions}

From the experimental work, it can be concluded that the incorporation of papermaking residues such as dregs and grits in clinker production is technically viable and does not present appreciable environmental effects, either concerning contaminants in gaseous emissions or when cement is considered as a waste at the end of its lifecycle. Therefore, no additional waste management procedures should be necessary when compared with normal construction and demolition residues. As a consequence, this method may be an alternative waste management route for these papermaking residues, avoiding their landfill and giving some value to the lime rich containing materials. However, it is recommended that the incorporation levels should be kept at low values, especially in the case of dregs, in order to avoid that sulphur dioxide emissions to the atmosphere overshoot the legal limits.

\section{References}

Andrade, F.R.D., Maringolo, V. and Kihara, Y. (2003) 'Incorporation of V, $\mathrm{Zn}$ and $\mathrm{Pb}$ into the crystalline phases of Portland clinker', Cement and Concrete Research, Vol. 33, pp.63-71.

Barros, A.M., Tenório, J.A.S. and Espinosa, D.C.R. (2004) 'Evaluation of the incorporation ratio of $\mathrm{ZnO}, \mathrm{PbO}$ and $\mathrm{CdO}$ into cement clinker', Journal of Hazardous Materials, Vol. B112, pp.71-78.

Cabral, F., Ribeiro, H.M., Hilário, L., Machado, L. and Vasconcelos, E. (2008) 'Use of pulp mill inorganic wastes as alternative liming materials', Bioresource Technology, Vol. 99, pp.8294-8298.

Cabral, F., Vasconcelos, E., Goss, M.J. and Cordovil, C.M.d.S. (1998) 'The value, use and environmental impacts of pulp-mill sludge additions to forest and agricultural lands in Europe', Enviro. Rev, Vol. 6, pp.55-64.

Caponero, J. and Tenório, J.A.S. (2000) 'Laboratory testing of the use of phosphate-coating sludge in cement clinker', Resources, Conservation and Recycling, Vol. 29, pp.169-179.

Demir, I., Baspinar, M.S. and Orhan, M. (2005) 'Utilization of kraft pulp production residues in clay brick production’, Building and Environmental, Vol. 40, pp.1533-1537. 
DIN (1984) German Standard Determination of the Leachibility by Water DIN 38414-S4, October 1984.

EC (1975) 'European Council Directive 75/442/EEC of 15 July 1975 on waste', Official Journal L, 25 July, Vol. 194, pp.39-41.

EC (2000) 'Commission Decision 2000/532/CE of 3 May 2000', Official Journal L, Vol. 226, 6 September, pp.3-24, modified by Commission Decisions 2001/118/CE of 16 January, 2001/119/CE of 22 January and 2001/573/CE of 23 July.

ECOCERAM 2 (2005) ECOCERAM 2 Project. Industrial Validation of Inorganic Residues Inertization in Ceramic Materials, POCTI Project - Medida 2.3/PXXI, Agência de Inovação, (2003-2005).

ECOINERT (1999) ECOINERT Project. Inertization of Metallurgical Residues by Stabilisation in Ceramic Products, Craft Project BE-S2-2260, (1998-99).

Galbenis, C-T. and Tsimas, S. (2006) 'Use of construction and demolition wastes as raw materials in cement clinker production', China Particuology, Vol. 4, No. 2, pp.83-85.

Gemelli, E., Heriberto, N., Camargo, A. and Brescansin, J. (2001) 'Evaluation of paper industry wastes in construction material applications', Materials Research, Vol. 4, No. 4.

Jordan, M., Sánchez, M.A., Padilla, L., Céspedes, R., Osses, M. and González, B. (2002) 'Kraft mill residues effects on Monterey pine growth and soil microbial activity', J. Environm. Qual, Vol. 31, pp.1004-1009.

Magalhães, M., Silva, J.E., Castro, F.P. and Labrincha, J.A. (2004a) 'Effect of experimental variables on the inertization of galvanic sludges in clay-based ceramics', Journal of Hazardous Materials, Vol. 106B, pp.139-147.

Magalhães, M., Silva, J.E., Castro, F.P. and Labrincha, J.A. (2004b) 'Role of the mixing conditions and composition of galvanic sludges on the inertization process in clay-based ceramics', Journal of Hazardous Materials, Vol. 106B, pp.169-176.

Martins, F., Matins, J., Ferracin, L. and Cunha, C. (2007) 'Mineral phases of green liquor dregs, slaker grits, lime mud and wood ash of a kraft pulp and paper mill', Journal of Hazardous Materials, Vol. 147, pp.610-617.

Muse, J.K. and Mitchell, C.C. (1995) 'Paper mill boiler ash and lime by products as soil liming materials', Agron. J., Vol. 87, pp.432-438.

Nurmesniemi, H., Poykio, R. and Keiki, R.L. (2007) 'A case study of waste management at the Northern Finnish pulp and paper mill complex of Stora Enso Veitsiluoto Mills', Waste Management, Vol. 27, pp.1939-1948.

Nurmesniemi, H., Poykio, R., Peramaki, P. and Kuokkanen, T. (2005) 'The use of a sequential leaching procedure for heavy metal fractionation in green liquor dregs from a causticizing process at a pulp mill', Chemosphere, Vol. 61, pp.1475-1484.

PT Decree (2002) 'Portuguese Decree 152/2002 of 23 May 2002', Diário da Republica, Série IMinistério do Ambiente e do Ordenamento do Território, Parte A, No. 119, pp.4680-4699.

Rossetti, V. and Medici, F. (1995) 'Inertization of toxic metals in cement matrices: effects on hydration, setting and hardening', Cement and Concrete Research, Vol. 25, No. 6, pp.1147-1152.

Saikia, N., Kato, S. and Kojima, T. (2007) 'Production of cement clinkers from municipal solid waste incineration (MSWI) fly ash', Waste Management, Vol. 27, pp.1178-1189.

Trezza, M.A. and Scian, A.N. (2007) 'Waste with chrome in the Portland cement clinker production', Journal of Hazardous Materials, Vol. 147, pp.188-196.

Tsakiridis, P.E., Papadimitriou, G.D., Tsivilis, S. and Koroneos, C. (2008) 'Utilization of steel slag for Portland cement clinker production', Journal of Hazardous Materials, Vol. 152, pp.805-811. 